Sari Pediatri, Vol. 6, No. 1, Juni 2004: 16-22

\title{
Purpura Trombositopenik Idiopatika pada Anak (patofisiologi, tata laksana serta kontroversinya)
}

\author{
Bagus Setyoboedi, IDG Ugrasena
}

\begin{abstract}
Purpura trombositopenik idiopatika (ITP) merupakan kelainan perdarahan didapat pada anak yang paling sering dijumpai, ITP merupakan kelainan otoimun yang menyebabkan munculnya suatu autoantibodi terhadap trombosit. Diagnosis ITP ditegakkan dengan menyingkirkan kemungkinan penyebab trombositopenia yang lain. Pemeriksaan aspirasi sumsum tulang tidak rutin dilakukan pada ITP, hanya untuk kasus yang meragukan. Pada anak umumnya ITP bersifat akut dan dapat sembuh spontan dalam waktu kurang dari 6 bulan. Tata laksana ITP khususnya ITP akut pada anak masih kontroversial. Pengobatan umumnya dilakukan hanya untuk meningkatkan jumlah trombosit, namun tidak menghilangkan risiko terjadinya perdarahan intrakranial dan perjalanan menjadi ITP kronis. Pengobatan juga potensial menimbulkan efek samping yang cukup serius. Perlu dilakukan suatu studi prospektif acak yang meneliti manfaat secara klinis berbagai pengobatan ITP pada anak. Pemahaman yang tepat tentang perjalanan alamiah ITP kronis pada anak sangat bermanfaat bagi suatu pengobatan yang rasional.
\end{abstract}

Kata kunci: purpura trombositopenik idiopatika akut dan kronik

$\mathrm{P}$ urpura trombositopenik idiopatika ialah suatu penyakit perdarahan didapat (acquired) sebagai akibat dari penghancuran trombosit yang berlebihan, ditandai dengan trombositopenia (trombosit $<150.000 / \mathrm{mm}^{3}$ ), purpura, gambaran darah tepi yang umumnya normal, dan tidak ditemukan penyebab trombositopenia yang lainnya. Klasifikasi ITP adalah akut dan kronik disebut kronik bila trombositopenia menetap lebih dari 6 bulan. ${ }^{1}$ Diperkirakan ITP merupakan salah satu penyebab kelainan perdarahan didapat yang banyak ditemukan oleh dokter anak, dengan insiden penyakit simtomatik berkisar 3 sampai 8 per 100.000 anak pertahun. ${ }^{2,3} \mathrm{Di}$ Bagian Anak RSUD Dr. Soetomo terdapat 22 kasus baru pada tahun 2000. Umumnya ditemukan pada anak berusia antara 2 sampai 10 tahun, tidak terdapat

\footnotetext{
Alamat Korespondensi:

IDG Ugrasena.,Dr,SpA(K).

Bagian Ilmu Kesehatan Anak FK-TDC UNAIR RS Dr. Soetomo Surabaya.

Jl Prof. Dr. Moestopo 6-8. Surabaya, 60132. 40061/3916.
}

perbedaan insiden antara laki-laki dan perempuan. ${ }^{2}$ Kelainan ini juga bisa terjadi pada bayi yang dilahirkan oleh ibu yang juga menderita ITP. ${ }^{4}$

Penyebab ITP adalah kelainan autoimun sehingga penghancuran trombosit dalam sistem retikuloendotelial meningkat. Kelainan ini biasanya menyertai infeksi virus atau imunisasi yang disebabkan oleh respon sistem imun yang tidak tepat (inappropriate). Akhir-akhir ini ITP juga sering disebut sebagai immune thrombocytopenic purpura (purpura trombositopeni imun). Diagnosis ITP sebagian besar ditegakkan berdasarkan gambaran klinis adanya gejala dan atau tanda perdarahan, disertai penurunan jumlah trombosit (trombositopenia). Pemeriksaan laboratorium lainnya dapat membantu menyingkirkan kemungkinan penyebab trombositopenia yang lain. Meskipun ITP pada anak umumnya bersifat akut, dan biasanya membaik dengan sendirinya dalam beberapa minggu sampai beberapa bulan, namun sejak seperempat abad yang lalu terdapat perbedaan pendapat di antara para ahli tentang pemberian prednison secara rutin pada penderita ITP. Dengan diperkenalkannya beberapa 
pengobatan baru akhir-akhir ini, semakin meramaikan perbedaan pendapat tersebut. Permasalahan dalam tata laksana ITP adalah apakah seharusnya pada semua penderita ITP, terutama anak-anak perlu diberikan pengobatan. ${ }^{5}$ Pada sebagian pasien, meskipun telah mendapatkan pengobatan tetap tidak membaik sampai lebih dari 6 bulan dan mengalami perjalanan penyakit menjadi ITP kronis.

Makalah ini membahas tentang ITP pada anak, terutama mengenai patofisiologi, tata laksanaan dan kontroversinya

\section{Patofisiologi}

Mekanisme terjadinya trombositopenia pada ITP ternyata lebih kompleks dari yang semula diduga. Kerusakan trombosit pada ITP melibatkan otoantibodi terhadap glikoprotein yang terdapat pada membran trombosit. Sehingga terjadi penghancuran terhadap trombosit yang diselimuti antibodi (antibody-coated platelets) oleh makrofag yang terdapat pada limpa dan organ retikuloendotelial lainnya. ${ }^{1}$ Megakariosit dalam sumsum tulang bisa normal atau meningkat pada ITP. ${ }^{1}$ Sedangkan kadar trombopoitin dalam plasma yang merupakan progenitor proliferasi dan maturasi dari trombosit mengalami penurunan yang berarti, terutama pada ITP kronis. ${ }^{1,6}$

Adanya perbedaan secara klinis maupun epidemiologis antara ITP akut dan kronis, menimbulkan dugaan adanya perbedaan mekanisme patofisiologi terjadinya trombositopenia di antara keduanya. Pada ITP akut, telah dipercaya bahwa penghancuran trombosit meningkat karena adanya antibodi yang dibentuk saat terjadi respon imun terhadap infeksi bakteri/virus atau pada pemberian imunisasi, yang bereaksi silang dengan antigen dari trombosit. Mediator-mediator lain yang meningkat selama terjadinya respon imun terhadap infeksi, dapat berperan dalam terjadinya penekanan terhadap produksi trombosit. Pada ITP kronis mungkin telah terjadi gangguan dalam regulasi sistem imun seperti pada penyakit otoimun lainnya, yang berakibat terbentuknya antibodi spesifik terhadap trombosit. ${ }^{1}$ Saat ini telah diidentifikasi beberapa jenis glikoprotein permukaan trombosit pada ITP, di antaranya GP IIbIIa, GP Ib, dan GP V. ${ }^{7-9}$ Namun bagaimana antibodi antitrombosit meningkat pada ITP, perbedaan secara pasti patofisiologi ITP akut dan kronis, serta komponen yang terlibat dalam regulasinya masih belum diketahui. ${ }^{1} \mathrm{Hal}$ tersebut di atas menjelaskan mengapa beberapa cara pengobatan terbaru yang digunakan dalam penatalaksanaan ITP memiliki efektifitas terbatas, dikarenakan mereka gagal mencapai target spesifik jalur imunologis yang bertanggung jawab pada perubahan produksi dan destruksi trombosit. $^{1,10}$

\section{Diagnosis}

Pada umumnya pasien ITP tampak sehat, namun tibatiba mengalami perdarahan pada kulit (petekie atau purpura) atau pada mukosa hidung (epistaksis). ${ }^{10}$ Perlu juga dicari riwayat tentang penggunaan obat atau bahan lain yang dapat menyebabkan trombositopenia. Riwayat keluarga umumnya tidak didapatkan. ${ }^{10,11}$ Pada pemeriksaan fisik biasanya hanya didapatkan bukti adanya perdarahan tipe trombosit (platelet-type bleeding), yaitu petekie, purpura, perdarahan konjungtiva, atau perdarahan mukokutaneus lainnya. ${ }^{10,11}$ Perlu dipikirkan kemungkinan suatu penyakit lain, jika ditemukan adanya pembesaran hati dan atau limpa, meskipun ujung limpa sedikit teraba pada lebih kurang $10 \%$ anak dengan ITP. ${ }^{1,10}$

Selain trombositopenia, pemeriksaan darah tepi lainnya pada anak dengan ITP umumnya normal sesuai umurnya. ${ }^{1,5,10,11}$ Pada lebih kurang 15\% penderita didapatkan anemia ringan karena perdarahan yang dialaminya. ${ }^{1}$ Pemeriksaan hapusan darah tepi diperlukan untuk menyingkirkan kemungkinan pseudotrombositopenia, sindrom trombosit raksasa yang diturunkan (inherited giant platelet syndrome), dan kelainan hematologi lainnya. ${ }^{10}$ Trombosit yang imatur (megatrombosit) ditemukan pada sebagian besar penderita. ${ }^{1,10,11}$ Pada pemeriksaan dengan flow cytometry terlihat trombosit pada ITP lebih aktif secara metabolik, ${ }^{12}$ yang menjelaskan mengapa dengan jumlah trombosit yang sama, perdarahan lebih jarang didapatkan pada ITP dibanding pada kegagalan sumsum tulang. ${ }^{10}$

Pemeriksaan aspirasi sumsum tulang pada anak dengan dugaan ITP, masih menimbulkan perbedaan pendapat di antara para ahli. . $^{10,13}$ Umumnya pemeriksaan ini dilakukan pada kasus-kasus yang meragukan, ${ }^{14,15}$ namun tidak pada kasus-kasus dengan manifestasi klinis yang khas. ${ }^{16}$ Pemeriksaan sumsum tulang dianjurkan pada kasus-kasus yang tidak khas ${ }^{1}$, 
misalnya pada

- Riwayat penyakit dan pemeriksaan fisik yang tidak umum, misalnya demam, penurunan berat badan, kelemahan, nyeri tulang, pembesaran hati dan atau limpa.

- Kelainan eritrosit dan leukosit pada pemeriksaan darah tepi

- Kasus yang akan diobati dengan steroid, baik sebagai pengobatan awal atau yang gagal diterapi dengan imunoglobulin intravena.

Pemeriksaan lain yang dapat dilakukan pada penderita ITP adalah mengukur antibodi yang berhubungan dengan trombosit (platelet-associated antibody) dengan menggunakan direct assay. Namun pemeriksaan ini juga belum dapat membedakan ITP primer dengan sekunder, atau anak yang akan sembuh dengan sendirinya dengan yang akan mengalami perjalanan menjadi kronis. ${ }^{17}$ Diagnosis ITP ditegakkan dengan menyingkirkan kemungkinan penyebab trombositopenia yang lain. ${ }^{10}$ Bentuk sekunder kelainan ini didapatkan bersamaan dengan systemic lupus erythematosus (SLE), sindroma antifosfolipid, leukemia atau limfoma, defisiensi IgA, hipogamaglobulinemia, infeksi HIV atau hepatitis $\mathrm{C}$, dan pengobatan dengan heparin atau quinidine. ${ }^{1,10,11}$

\section{Tata laksana}

Tata laksana ITP pada anak meliputi tindakan suportif dan terapi farmakologis. Tindakan suportif merupakan hal yang penting dalam penatalaksanaan ITP pada anak, di antaranya membatasi aktifitas fisik, mencegah perdarahan akibat trauma, menghindari obat yang dapat menekan produksi trombosit atau merubah fungsinya, dan yang tidak kalah pentingnya adalah memberi pengertian pada pasien dan atau orang tua tentang penyakitnya. ${ }^{18,19}$

Sebagian besar kasus ITP pada anak tidak perlu dirawat di rumah sakit, oleh karena dapat sembuh sempurna secara spontan dalam waktu kurang dari 6 bulan. ${ }^{1,5,11}$ Pada beberapa kasus ITP pada anak didapatkan perdarahan kulit yang menetap, perdarahan mukosa, atau perdarahan internal yang mengancam jiwa yang memerlukan tindakan atau pengobatan segera. ${ }^{5,10}$ Transfusi trombosit jarang dilakukan dan biasanya tidak efektif, karena trombosit yang ditransfusikan langsung dirusak. ${ }^{5}$
Obat-obat yang dapat menyebabkan trombositopeni, adalah obat yang dapat menurunkan produksi trombosit

- Obat-obat kemoterapi

- Thiazide

- Alkohol

- Estrogen

- Kloramfenikol

- Radiasi

Obat yang dapat meningkatkan destruksi trombosit

- Sulfonamid

- Quinidine

- Quinine

- Carbamazepin

- Asam valproat

- Heparin

- Digoksin

Obat yang berhubungan dengan perubahan fungsi trombosit

- Aspirin

- Dipiridamol

Kekambuhan secara mendadak biasanya jarang didapatkan. ${ }^{5}$ Pada penderita yang jumlah trombositnya tidak mencapai nilai normal dalam 6 bulan, maka diagnosis berubah menjadi ITP kronik. ${ }^{1,5,10,11}$ Perdarahan yang serius jarang didapatkan pada ITP, insiden perdarahan otak pada ITP dalam minggu pertama hanya berkisar $0,1-0,2 \%$, namun meningkat menjadi $1 \%$ pada mereka dengan jumlah trombosit kurang dari $20.000 / \mathrm{mm}^{3}$ setelah 6-12 bulan. ${ }^{3}$ Perdarahan otak pada ITP tidak selalu berakibat fatal, ${ }^{20}$ dan pengobatan tidak mengurangi risiko terjadinya perdarahan otak pada ITP. ${ }^{21}$

Pengobatan yang biasa diberikan pada anak dengan ITP meliputi kortikosteroid peroral, imunoglobulin intravena (IVIG), dan yang terakhir, anti-D untuk kasus dengan rhesus D positif., ${ }^{1,511,14}$ Pengobatan tersebut potensial memberikan efek samping yang serius, sehingga penting bagi kita untuk mempertimbangkan risiko-risiko tersebut agar tidak merugikan pasien (primum non nocere). ${ }^{22}$

Sebelum era IVIG, kortikosteroid per oral merupakan pengobatan utama pada ITP karena dipercaya dapat menghambat penghancuran trombosit dalam sistem retikuloendotelial dan mengurangi pembentukan antibodi terhadap trombosit, serta mempunyai efek stabilisasi kapiler yang dapat mengurangi perdarahan. Buchanan dan Holtkamp 
(1984) melakukan penelitian tentang efektifitas kortikosteroid peroral pada dosis standar $(2 \mathrm{mg} / \mathrm{kgbb} /$ hari) sebagai pengobatan ITP akut. Berdasarkan jumlah trombosit, waktu perdarahan, dan gejala klinis, tidak didapatkan perbedaaan yang bermakna antara kelompok prednison dan plasebo kecuali pada pengobatan hari ke-7. ${ }^{23}$ Penelitian terbaru menunjukkan respon yang lebih cepat (secepat IVIG) dalam menaikkan jumlah trombosit pada dosis prednison yang lebih tinggi ( $4 \mathrm{mg} / \mathrm{kgbb} / \mathrm{hr})$ jangka pendek. ${ }^{24}$

Beberapa penelitian menunjukkan peningkatan yang cepat jumlah trombosit dengan efek samping yang minimal pada pengobatan IVIG. ${ }^{25}$ Seperti kortikosteroid, IVIG juga menyebabkan blokade pada sistem retikuloendotelial yang dapat meningkatkan jumlah trombosit dalam waktu cepat (umumnya dalam 48 jam), sehingga merupakan pengobatan pilihan untuk ITP dengan perdarahan yang serius (berat secara klinis). ${ }^{13}$ Meskipun IVIG telah populer digunakan dalam terapi ITP pada anak, data terbaru menunjukkan lebih dari $75 \%$ anak mengalami efek samping nyeri kepala dan panas. Beberapa mengalami efek samping yang lebih serius, yaitu iritasi meningeal dan hemiplegia sementara. Oleh karena itu, sebaiknya IVIG tidak diberikan tanpa indikasi yang jelas, apalagi kalau hanya untuk menaikkan jumlah trombosit saja. ${ }^{13}$

Pengobatan dengan imunoglobulin anti-D efektif pada anak dengan rhesus positif dan memiliki keuntungan berupa suntikan tunggal dalam waktu singkat. ${ }^{26}$ Namun selain mahal, dilaporkan adanya hemolisis dan anemia yang memerlukan transfusi darah setelah pengobatan. ${ }^{27}$ Terdapat beberapa penelitian yang membandingkan kombinasi dari beberapa pilihan pengobatan meliputi tanpa terapi, prednison peroral, metilprednisolon dosis tinggi, IVIG, dan imunoglobulin anti-D intravena.

Imbach, dkk (1985) ${ }^{24}$ melakukan penelitian pertama yang membandingkan IVIG dan steroid. Tidak didapatkan perbedaan respon yang bermakna antara keduanya pada anak yang jumlah trombosit meningkat $>30.000 / \mu \mathrm{l}$ dalam waktu 10 hari, namun IVIG lebih baik pada mereka yang trombositnya meningkat $>30.000 / / \mu \mathrm{l}$ dalam waktu $>10$ hari.

Albayrak, dkk (1994) ${ }^{28}$ membandingkan metilprednisolon dosis tinggi $(30 \mathrm{mg} / \mathrm{kgbb} / \mathrm{hr}$ dan $50 \mathrm{mg} /$ $\mathrm{kgbb} / \mathrm{hr}$ selama 7 hari) dengan IVIG $(0,5 \mathrm{~g} / \mathrm{kgbb} / \mathrm{hr}$ selama 5 dosis) untuk pengobatan ITP akut. Tidak didapatkan perbedaan yang bermakna dalam meningkatkan jumlah trombosit di antara ketiganya.
Proses kesembuhan akan terjadi secara spontan pada anak dengan ITP, namun mungkin dipercepat dengan pemberian kortikosteroid dosis tinggi atau IVIG, respon tersebut sering hanya bersifat sementara dan tidak memberi perlindungan terhadap komplikasi perdarahan hebat yang dapat mengancam jiwa. Juga tidak didapatkan data yang menunjukkan bahwa pengobatan tersebut menurunkan kemungkinan menjadi ITP kronis. ${ }^{5}$ Pemberian steroid jangka panjang sebaiknya dihindari karena risiko efek samping yang mungkin lebih membahayakan dari penyakitnya sendiri. ${ }^{13}$ Splenektomi jarang dilakukan pada anak dengan ITP dan hanya dianjurkan pada perdarahan hebat yang tidak memberikan respon terhadap pengobatan, dan dilakukan setelah menjadi ITP kronis ( $>6$ bulan). ${ }^{29}$ Angka kegagalan splenektomi berkisar $25-30 \%$ dan mungkin lebih besar (>60\%) dengan pengamatan jangka panjang. Splenektomi, meskipun jarang berhubungan dengan peningkatan risiko terjadinya sepsis walaupun telah diberikan vaksinasi pnemokokus dan profilaksis penisilin. ${ }^{30}$

Beberapa pengobatan lain yang pernah dilaporkan bisa diberikan pada anak dengan ITP adalah; $\gamma$ interferon, transfusi tukar plasma dan protein $A$ immunoadsorption, alkaloid Vinca (vinkristin dan vinblastin), danazol, vitamin C, dan siklofosfamid. ${ }^{11,20}$

\section{Kontroversi dalam Tata laksana}

Tata laksana ITP akut pada anak masih menjadi topik kontroversi. Sebagian dokter meyakini perjalanan alami yang ringan penyakit tersebut dan menganjurkan pengobatan hanya untuk mereka yang mengalami perdarahan secara klinis berupa petekie dan atau purpura yang banyak sampai perdarahan hebat yang mengancam jiwa. Sedangkan sebagian yang lain menganjurkan tindakan dan pengobatan dini pada semua anak dengan trombosit kurang dari 20.000$30.000 / \mathrm{mm}^{3}$ tanpa menghiraukan tingkat perdarahan. ${ }^{5}$

Di Bagian Ilmu Kesehatan Anak RSUD Dr. Soetomo Surabaya, kasus ITP akut dengan perdarahan ringan berupa petekie atau purpura dirawat, tidak diberikan pengobatan hanya dilakukan observasi dan pemberian roboransia. Jika terjadi perdarahan yang lebih berat berat (epistaksis, perdarahan kulit yang luas,perdarahan gusi serta melena), diberi prednison $60 \mathrm{mg} / \mathrm{m}^{2} / \mathrm{hr}$ selama 4 minggu dan suspensi trombosit jika dicurigai ada perdarahan intra kranial. Bila tidak 
terjadi kesembuhan dalam waktu 12-24 minggu maka pengobatan prednison diberikan bersama-sama azathiophrine 1-2 mg/kg bb, Pada ITP kronis diberi IVIG 400-600 mg/kgbb/hr selama 3-5 hari. Apabila belum sembuh juga maka dipertimbangkan untuk dilakukan splenektomi. Apabila penghancuran trombosit juga terjadi pada hati, maka umumnya splenektomi tidak akan memberikan hasil yang memuaskan. Sedangkan di Divisi Hematologi IKA FKUI/RSCM semua pasien ITP dirawat karena dikuatirkan timbulnya perdarahan intrakranial. Jika saat masuk disertai perdarahan (epistaksis, perdarahan gusi, melena, perdarahan kulit yang luas), maka pengobatan diberikan seperti pasien ITP kronis yaitu prednison $2 \mathrm{mg} / \mathrm{kgbb}$ selama 3-6 bulan dan suspensi trombosit bila diperlukan. Bila belum sembuh selama 3-6 bulan, maka pengobatan prednison diberikan bersama azathiophrine (imuran) $1-2 \mathrm{mg} / \mathrm{kgbb}$. Bila belum sembuh juga, maka dipertimbangkan tindakan splenektomi. ${ }^{31}$ Sebagian besar ahli hematologi anak di Inggris berpendapat bahwa sebagian besar anak dengan ITP akut tidak memerlukan pengobatan aktif. Hal tersebut bertolak belakang dengan petunjuk praktis yang ada di Amerika Serikat, ${ }^{16}$ yang memberi pengobatan bila didapatkan jumlah trombosit yang rendah $\left(<20.000-30.000 / \mathrm{mm}^{3}\right)$. Hal tersebut dilakukan untuk menjaga kemungkinan terjadinya perdarahan intrakranial. ${ }^{10}$

Permasalahan yang terjadi adalah kenyataan bahwa belum cukup penelitian yang baik yang bisa dijadikan dasar penentuan keputusan. Penelitian-penelitian yang ada lebih banyak menggunakan jumlah trombosit sebagai hasil akhir dibanding parameter klinis. ${ }^{13}$ Satu pengamatan terbaru dari beberapa kasus dengan perdarahan yang lebih serius pada ITP, didapatkan bahwa pengobatan meningkatkan jumlah trombosit sehari setelahnya hanya dalam jumlah kecil kasus. ${ }^{32}$ Hingga saat ini belum ada penelitian yang mengevaluasi respon klinis secara menyeluruh terhadap pengobatan (atau tanpa pengobatan) pada anak dengan ITP. Selain itu, pembahasan tentang kualitas hidup dan biaya berbagai macam pengobatan perlu dijadikan pusat perhatian.

\section{ITP Kronis}

Purpura Trombobositopenik idiopatika (ITP) dikatakan kronis jika trombositopeni menetap hingga lebih dari 6 bulan. ${ }^{36,33}$ Insden kelainan ini berkisar 1 dalam 250.000 anak tiap tahun, ${ }^{34}$ termasuk 10\%-20\% dari anak dengan ITP. Masih belum jelas apakah ITP akut dan kronis merupakan kelainan yang berbeda. Kelainan ini lebih banyak ditemukan pada anak yang lebih tua, terutama wanita muda. Biasanya disertai suatu penyakit yang mendasari atau didapatkan bukti adanya suatu perubahan imunitas. ${ }^{5}$

Pemahaman yang tepat tentang perjalanan alamiah ITP kronis pada anak sangat bermanfaat bagi suatu pengobatan yang rasional untuk kelainan tersebut yang masih kontroversial. Ada yang berpendapat bahwa pasien ITP kronis akan mengalami perdarahan berulang yang memerlukan splenektomi, infus IVIG yang teratur, atau obat-obat imunosupresan. Namun pandangan tersebut ditentang oleh beberapa kelompok peneliti ${ }^{34,35}$ yang berdasarkan suatu studi kasus yang besar mendapatkan bahwa sebenarnya ITP kronis merupakan suatu kondisi yang ringan, hanya sedikit di antara mereka yang mengalami perdarahan yang berat.

Banyak di antara anak dengan ITP kronis dapat mempertahankan jumlah trombosit mereka $>30.000$ / $/ \mu \mathrm{l}$ tanpa pengobatan. ${ }^{5}$ Pada suatu pengamatan jangka panjang anak dengan ITP kronis memperlihatkan bahwa kesembuhan dalam jangka waktu yang lama masih bisa terjadi bahkan sampai $>10$ tahun. Diperkirakan angka kesembuhan spontan setelah 15 tahun berkisar $61 \%,{ }^{34}$ hampir sama dengan $63 \%$ pada penelitian yang lain. ${ }^{36}$

Pada ITP kronis umumnya ringan dan kesembuhan spontan kadang-kadang masih bisa terjadi, maka pengobatan sifatnya individual. Kecuali splenektomi, tidak ditemukan data yang memperlihatkan manfaat dari berbagai macam terapi ITP kronis yang ada. ${ }^{5}$ Banyak di antara penderita ITP kronis yang tidak sembuh, meskipun dengan trombositopeni yang sedang tidak disertai gejala klinis yang berarti. Sebagian besar dapat hidup dengan perdarahan ringan pada kulit dan sedikit keterbatasan, pengobatan sebaiknya diberikan jika dilakukan tindakan pembedahan dan kecelakaan. ${ }^{13}$

\section{Daftar Pustaka}

1. Yu WC, Korb J, Sakamoto KM. Idiopathic trombocytopenic purpura. Pediatr Rev 2000;21:95-103.

2. Frederiksen H, Schmidt K. The incidence of idiopathic thrombocytopenic purpura in adults increase with age. 
Sari Pediatri, Vol. 6, No. 1, Juni 2004

Blood 1999;94:909-13.

3. Lilleyman JS. Intracranial haemorrhage in idiopathic thrombocytopenic purpura. Arch Dis Child 1994;71: 251-3.

4. Gill KK, Kelton JG. Managemrnt of idiopathic thrombocytopenic purpura in pregnancy. Semin Hematol 2000;37:275-89.

5. Medeiros D, Buchanan GR. Current controversies in the management of idiopathic thrombocytopenic purpura during childhood. Pediatr Clin North Am 1996;43:757-72.

6. Emmons RVB, Reid DM, Cohen RJ, dkk. Human Thrombopoietin level are high when thrombocytopenia is due to megakaryocyte deficiency and low when thrombocytopenia is due to increased platelet destruction. Blood 1996;87:4068-71.

7. Kunicki TJ, Newman PJ. The molecular immunology of human platelet protein. Blood 1992;80:1386-1404.

8. Escher R, Muller D, Vogel M, dkk. Recombinant human natural autoantibodies against GP IIb/IIIa inhibit binding of autoantibodies from patieny with AITP. Br J Haematol 1998;102:820-8.

9. Bowditch RD, Tani P, Fong KC, McMillan R. Characterization of autoantigenic epitopes on platelet glycoprotein IIb/IIIa using random peptide libraries. Blood 1996;88:4579-84.

10. Douglas B, Cines MD, Immune thrombocytopenic purpura. N Engl J Med 2002;346:995-1008.

11. Imbach P. Immune thrombocytopenic purpura. Dalam: Lilleyman JS, Hann IM, Blanchette VS, penyunting. Pediatric Hematology, edisi ke 2. New York: Churchill Livingstone, 1998;437-47.

12. Saxon HR, Mody M, Blanchette VS, Freedman J. Reticulated platelet counts in the assessmentof thrombocytopenic disorders. Acta Paediatr Suppl 1998;424:6570.

13. Bolton-Maggs PH. Idiopathic thrombocytopenic purpura. Arch Dis Child 2000;83:220-2.

14. Halperin DS, Doyle JJ. Is bone marrow examination justified in idiopathic thrombocytopenic purpura? Am J Dia Child 1998;142:508-11.

15. Calpin C, Dick P, Poon A, Fieldman W. Is bone marrow aspiration needed in acute childhood idiopathic thrombocytopenic purpura to rule out leukaemia? Arch Pediatr Adolesc Med 1998;152:345-7.

16. George JN, WoolfSH, Raskob GE, dkk. Idiopathic thrombocytopenic purpura: a practice guideline developed by explicit methods for the American Society of Hematology. Didapatkan pada : http://www.hematology.org/education/ idiopathic.cfm (24 April 2002)

17. Taub JW, Warrier I, dkk. Characterization of autoantibodies against the platelet glycoprotein IIb/IIIa in childhood idiopathic thrombocytopenic purpura. Am J Hematol 1995;48:104-7.

18. Lanzkowsky P. Manual of pediatric haematology and oncology, edisi ke 2. New York: Churchill Livingstone, 1995. h. 196-201.

19. Corrigan JJ. Platelet and vascular disorders. Dalam: Miller DR, Baehner RL, penyunting. Blood disease of infancy and childhood, edisi ke 6. Philadelphia: Mosby co 1990. h. 793-5.

20. Lilleyman JS. Intracranial haemorrhage in idiopathic thrombocytopenic purpura. Pediatric Haematology Forum of the British Society for Haematology. Arch Dis Child 1994;71:251-3.

21. Imbach P, dkk. Intravenous immunoglobulin versus oral corticosteroids in acute immune thrombocytopenic purpura in childhood. Lancet 1985;ii:464-8.

22. Chessells J. Chronic idiopathic thrombocytopenic purpura: primum non nocere. Arch Dis Child 1989;64: 1326-8.

23. Buchanan GR, Holtkamp CA. Prednison therapy for children with newly diagnosed idiopathic thrombocytopenic purpura: A randomized clinical trial. Am J Pediatr Hematol Oncol 1984;6:355-61.

24. Carcao MD, Zipursky A, dkk. Short-course oral prednisone therapy in children presenting with acute immune thrombocytopenic purpura (ITP). Acta Paediatr Suppl 1998;424:71-4.

25. Bussel JB, Goldman A, Imbach P, dkk. Treatment of acute idiopathic thrombocytopenia of childhood with intravenous infusions of gamma globulin. J Pediatr 1985;106:886-90.

26. Tarantino MD, dkk. Treatment of childhood acute immune thrombocytopenic purpura with anti-D immune globulin or pooled immune globulin. J Pediatr 1999;134:21-6.

27. Gaines A. Acute onset hemoglobinemia and/or hemoglobinuria and sequelae following $\mathrm{Rh}_{\mathrm{o}}(\mathrm{D})$ immune globulin intravenous administration in immune thrombocytopenic purpura patients. Blood 2000;95:2523-9.

28. Albayrak D, dkk. Acute immune thrombocytopenic purpura: A comparative study of very high oral doses of methylprednisolone and intravenously administrated immune globulin. J Pediatr 1994;125:1004-7.

29. Eden OB, Lilleyman JS. Guidelines for management idiopathic thrombocytopenic purpura. The British Paediatric Haematology Group. Arch Dis Child 1992;67: 
1056-8

30. Waghorn D, Mayon-White R. A study of 42 episodes of overwhelming post-splenectomy infection: is guidance for asplenic individuals being followed? J Infect 1997;35:289-94.

31. Munthe BG. Purpura trombositopenik idiopatik. Dalam: Wahidiyat I, Gatot D, Mangunatmadja I, penyunting. Naskah lengkap pendidikan tambahan berkala ilmu kesehatan anak ke XXIV. Jakarta 1996:69-77.

32. Mederios D, Buchanan GR. Major hemorrhage in children with idopathic thrombocytopenic purpura immediate response to therapy and long-term outcome. J
Pediatr 1998;133:334-9.

33. Buchanan GR. ITP: How much treatment is enough? Contemp pediatr 1995;12:23-48.

34. Reid MM. Chronic idiopathic thrombocytopenic purpura: incidence, treatment, and outcome. Arch Dis Child 1995;72:125-8.

35. Tait RC, Evans DIK. Late spontaneous recovery of chronic thrombocytopenia. Arch Dis Child 1993;68: 680-1.

36. Tamary H, Kaplinsky C, Levy I, dkk. Chronic childhood idiopathic thrombocytopenic purpura: long-term follow-up. Acta pediatr 1994;83:931-4. 